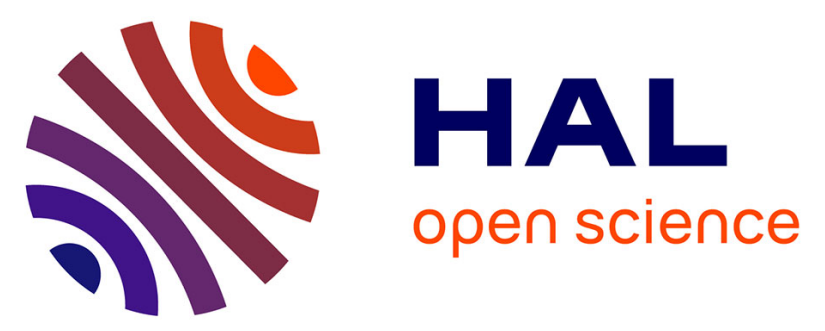

\title{
Infectivity enhancement of different HIV-1-based lentiviral pseudotypes in presence of the cationic amphipathic peptide LAH4-L1.
}

David Fenard, Sandrine Genries, Daniel Scherman, Anne Galy, Samia Martin, Antoine Kichler

\section{To cite this version:}

David Fenard, Sandrine Genries, Daniel Scherman, Anne Galy, Samia Martin, et al.. Infectivity enhancement of different HIV-1-based lentiviral pseudotypes in presence of the cationic amphipathic peptide LAH4-L1.. Journal of Virological Methods, 2013, 189 (2), pp.375-8. 10.1016/j.jviromet.2013.02.005 . inserm-00800499

\section{HAL Id: inserm-00800499 https://www.hal.inserm.fr/inserm-00800499}

Submitted on 14 Mar 2013

HAL is a multi-disciplinary open access archive for the deposit and dissemination of scientific research documents, whether they are published or not. The documents may come from teaching and research institutions in France or abroad, or from public or private research centers.
L'archive ouverte pluridisciplinaire HAL, est destinée au dépôt et à la diffusion de documents scientifiques de niveau recherche, publiés ou non, émanant des établissements d'enseignement et de recherche français ou étrangers, des laboratoires publics ou privés. 


\section{Infectivity enhancement of different HIV-1-based lentiviral pseudotypes in presence of the cationic amphipathic peptide LAH4-L1}

David Fenard $^{1,2,3} *$, Sandrine Genries ${ }^{1,2,3}$, Daniel Scherman ${ }^{4,5,6}$, Anne Galy ${ }^{1,2,3}$, Samia Martin ${ }^{1}$ and Antoine Kichler ${ }^{1,4,5,6}$

${ }^{1}$ Généthon, Evry F-91002, France; ${ }^{2}$ INSERM, UMR_S951, Généthon, Evry F-91002, France; ${ }^{3}$ Université Evry Val d'Essonne, UMR_S951, Evry F-91002, France; ${ }^{4}$ CNRS, UMR_8151, Paris F-75270, France; ${ }^{5}$ INSERM, U1022, Paris F-75270, France; ${ }^{6}$ Université Paris Descartes, Paris F-75270, France.

* Corresponding author at:

David Fenard, PhD

Généthon, INSERM UMR_S951,

1bis, rue de l'Internationale - BP60, F-91002 Evry Cedex, France

Tel : +33169472531

Fax : +33169472838

E-mail address : dfenard@genethon.fr (D.Fenard)

Keywords : Gene therapy; Hematopoietic stem cell; cationic amphipathic peptide; lentiviral vector. 


\begin{abstract}
Lentiviral vectors (LVs) are promising delivery systems for gene therapy. To enhance the efficiency of target cell transduction by LVs, protocols often include the addition of culture additives. In this study, the cationic amphipathic peptide LAH4-L1 (KKALLAHALHLLALLALHLAHALKKA), a DNA transfection agent, was evaluated for its capacity to improve LV infectivity in cell lines and primary cells. Results show that LAH4-L1 enhances infectivity of all LV pseudotypes tested, particularly GALVTR-LVs. More importantly, LAH4-L1 promotes the transduction of CD34+ hematopoietic stem cells with GALVTR-LVs as efficiently as Retronectin, a culture additive used in ex vivo clinical protocols involving LVs. The action of LAH4-L1 relies both on the GALVTR-LV adhesion and post-adhesion steps. LAH4-L1 represents a new and attractive transduction enhancer for hematopoietic gene therapy protocols.
\end{abstract}


Human immunodeficiency virus 1 (HIV-1)-based lentiviral vectors (LVs) are promising vehicles for gene therapy. Several clinical trials use LVs for ex vivo transduction of hematopoietic stem cells (HSCs) (D'Costa et al., 2009; Naldini, 2011). Transduction of HSCs by LVs is initiated by binding of the viral envelope glycoprotein (GP) to cell surface receptors. LVs can be efficiently pseudotyped with GPs harboring a broad tropism (e.g. the vesicular stomatitis virus GP (VSV-G)), but also GPs harboring a strong hematopoietic tropism, such as amphotropic murine leukemia virus GP (MLV-A), modified feline endogenous retrovirus RD114 GP (RD114TR) or modified gibbon ape leukemia virus GP (GALVTR) (Sandrin et al., 2002). However, a limiting factor that can be encountered during viral transduction is the optimal entry of LVs into target cells. One way to circumvent this hurdle is the addition of cofactors in transduction protocols like cationic polymers (e.g. polybrene) or fibronectin fragments (e.g. Retronectin) (Davis et al., 2004; Pollok and Williams, 1999). Since the cationic property appears crucial for many enhancers of retroviral infectivity, the capacity of a cationic amphipathic peptide to improve LV infectivity has been investigated. Notably, peptides are interesting for their biodegradable property, for their reduced size, simplicity of characterization and large-scale production. This study is focused on a 26 residues long cationic amphipathic peptide called LAH4-L1 (KKALLAHALHLLALLALHLAHALKKA), described previously as a potent DNA transfection agent (Mason et al., 2006b).

Pseudotyped LVs were generated by transient transfection of 293T cells with four plasmids (ratios 22:1:1:8): the transfer vector plasmid (pRRLsin-PPT-hPGK-eGFP-WPRE) encoding the green fluorescent protein (eGFP), the plasmid encoding HIV-1 Rev (pBA.Rev), the plasmid encoding HIV-1 gagpol (pKLgagpol), and the appropriate envelope glycoprotein constructs: pBA-GALVTR to generate GALVTR-LVs; pHCMV-RD114TR to generate RD114TR-LVs; pBA-Ampho to generate MLV-A-LVs; and pMDG to generate VSV-G-LVs. 
Viral supernatants were collected $48 \mathrm{~h}$ post-transfection, filtered $(0.45 \mu)$, aliquoted, and stored at $-80^{\circ} \mathrm{C}$. Viral titers were determined by flow cytometry after infection of HCT116 cells with serial dilutions of the vector (Merten et al., 2011). HCT116 cells are commonly used because of their high permissivity to numerous lentiviral pseudotypes (Barde et al., 2010). To study the effect of LAH4-L1 on LV infectivity, HCT116 cells were transduced either with the four LV pseudotypes at the same multiplicity of infection (MOI) of 0.6 , or with vector particles produced in absence of any envelope glycoprotein (virus-like particles, VLPs, 200ng of p24/ml) (Fig. 1A). Briefly, viral supernatants were pre-incubated $15 \mathrm{~min}$ at $37^{\circ} \mathrm{C}$ with different concentrations of LAH4-L1, and then loaded onto HCT116 cell layers. After $4 \mathrm{~h}$ post-transduction, cells were washed and further cultured for 3 days. Transduction efficiency was determined by monitoring eGFP expression using flow cytometry. As shown in Fig. 1A, LAH4-L1 promotes LV infectivity at different extent, with the highest effect observed for GALVTR-LVs (12-fold) and the lowest effect observed for VSV-G-LVs (nearly 3-fold) (Fig. 1B). Interestingly, VLPs are unable to transduce target cells, even in the presence of LAH4L1, indicating that LAH4-L1 is promoting infectivity through an envelope-dependent mechanism.

The GALVTR-LVs are commonly used in gene therapy protocols designed to target human hematopoietic progenitors (Jacome et al., 2009). The hCD34+ cells were obtained from umbilical cord blood (UCB) samples after column affinity purification and were preactivated with a cocktail of cytokines (see Charrier et al., 2007). UCBs for this study were obtained in accordance with international ethical principles and French national law under declaration $\mathrm{N}^{\circ}$ DC-201-1655 to the French Ministry of Research and Higher Studies. As shown in fig. $2 \mathrm{~A}$, the half maximal efficient concentration $\left(\mathrm{EC}_{50}\right)$ of LAH4-L1 on hCD34+ cells $\left(3.5 \times 10^{4}\right.$ cells/well) transduced with GALVTR-LVs is around $8 \mu \mathrm{g} / \mathrm{ml}$ (the average value of maximal transduction was $27 \%$ of GFP+ cells). In addition, the half maximal toxic 
concentration $\left(\mathrm{TC}_{50}\right)$ of LAH4-L1 on hCD34+ cells was determined. Briefly, hCD34+ cells were incubated overnight with the indicated amount of LAH4-L1. Next, the survival rate of hCD34+ cells was estimated using the Trypan blue exclusion method under light microscope. As shown in Fig. 2B, the $\mathrm{TC}_{50}$ of LAH4-L1 is around $48 \mu \mathrm{g} / \mathrm{ml}$ (the average value of survival rate in absence of LAH4-L1 was 98.9\%). Hence, the LAH4-L1 $\mathrm{TC}_{50} / \mathrm{EC}_{50}$ ratio represents a 6-fold safety index which permits a safe and practical use of this reagent for lentiviral transduction of hCD34+ cells. In conclusion, the optimal concentration of LAH4-L1, with no apparent toxicity on hCD34+ cells, has been defined around $12 \mu \mathrm{g} / \mathrm{ml}$ (transduction rate of $88 \pm 14 \%$ and survival rate of $100 \pm 02 \%)$.

Next, LAH4-L1 was able to promote the lentiviral transduction of hCD34+ cells from several UCB donors (Fig. 2C). It is important to note that the transduction with GALVTRLVs is nearly undetectable in absence of any transduction enhancer, while the effect of LAH4-L1 reproducibly increased transduction levels of hCD34+ cells in a vector-dose dependent manner (Fig. 2C).

Since hCD34+ cells are typically transduced with GALVTR-LVs pre-adsorbed onto Retronectin (Takara bio)-coated wells (Jacome et al., 2009; Pollok and Williams, 1999), the ability of LAH4-L1 to promote hCD34+ cells transduction was tested in comparison with Retronectin. The dynamic preloading protocol of GALVTR-LVs onto retronectin coated plates $\left(20 \mu \mathrm{g} / \mathrm{cm}^{2}\right)$ has been described previously (Jacome et al., 2009). In absence of Retronectin, hCD34+ cells were transduced with GALVTR-LVs pre-incubated 15 min with LAH4-L1. After $6 \mathrm{~h}$ of transduction at $37^{\circ} \mathrm{C}$, fresh medium was added to each well and transduction efficiency was evaluated by flow cytometry 4 days later. As shown in Fig. 2D, LAH4-L1 is promoting hCD34+ cells transduction as efficiently as Retronectin and with no detectable toxicity (data not shown). 
To determine whether LAH4-L1 is acting on the adhesion step and/or the post-binding events, we adapted a virus binding assay, described previously (Gummuluru et al., 2003) and depicted in Fig. 3A. Briefly, HCT116 cells were incubated with GALVTR-LVs during $3 \mathrm{~h}$ at $4^{\circ} \mathrm{C}$ to allow for viral adhesion, in the absence or presence of LAH4-L1 or polybrene (SigmaAldrich). Unbound GALVTR-LVs were then washed away and cells were either lysed to determine the amount of membrane bound p24 (ELISA p24 kit, Perkin Elmer) normalized to total protein contents (BCA protein assay, Pierce) or cultured for an additional 2 days to estimate transduction efficiency using flow cytometry (GFP+ cell percentages). As shown in Fig. 3B, LAH4-L1 is as efficient as polybrene to potentiate the adhesion step, probably through the cationic charges of these two compounds, leading to the neutralization of negative charges present on the target cell surface. Interestingly, the difference between polybrene and LAH4-L1 is highlighted on the post-binding events (Fig. 3C and D). After an extensive wash of unbound GALVTR-LVs, we observed that viral particles bound to cell surface are more prone for entry and subsequent transduction steps in presence of LAH4-L1 (index 2.6) than in presence of polybrene (index 1.7).

Amphipathic peptides such as LAH4-L1 interact with membrane lipids, adopt a transmembrane orientation at neutral $\mathrm{pH}$ and in consequence weakly disrupt the plasma membrane (Mason et al., 2006a). Since the lipid mixing between viral and plasma membrane seems a prerequisite to viral envelope engagement for viral pore formation (Chien et al., 2009), it is tempting to speculate that LAH4-L1, with its high affinity to membrane lipids, may act at the level of the entry step, first, by neutralizing anionic lipids and heparan sulfates and also by locally destabilizing the membrane lipid leaflet, leading finally to an optimization of the lipid mixing step independently of the envelope used to pseudotype the lentiviral vector. Furthermore, the fact that the optimal concentration of LAH4-L1 to promote lentiviral transduction $(12 \mu \mathrm{g} / \mathrm{ml})$ is too low to promote an efficient DNA transfection (not shown) 
suggests that LAH4-L1 exerts these two functions through different molecular mechanisms. In conclusion, LAH4-L1 represents a new and attractive transduction cofactor for future gene therapy developments involving LVs.

\section{Acknowledgements}

This work was supported by the Association Française contre les Myopathies. We are thankful to Genethon collaborators, in particular A. Viornery for technical assistance. We are very grateful to the mothers and staff of the Maternité de l'hôpital Louise Michel, Evry, France for providing us with umbilical cord blood samples. We also thank A.J. Mason and B. Bechinger for the gift of LAH4-L1 and F.L. Cosset for helpful discussion and the gift of GALVTR and RD114TR envelope glycoprotein constructs. 


\section{References}

Barde, I., Salmon, P., Trono, D., 2010. Production and titration of lentiviral vectors. Current Protocols in Neurosciences. 53: 4.21.1-4.21.23.

Charrier, S., Dupre, L., Scaramuzza, S., Jeanson-Leh, L., Blundell, M.P., Danos, O., Cattaneo, F., Aiuti, A., Eckenberg, R., Thrasher, A.J., Roncarolo, M.G., Galy, A., 2007. Lentiviral vectors targeting WASp expression to hematopoietic cells, efficiently transduce and correct cells from WAS patients. Gene Therapy 14, 415-28.

Chien, M.P., Lin, C.H., Chang, D.K., 2009. Recruitment of HIV-1 envelope occurs subsequent to lipid mixing: a fluorescence microscopic evidence. Retrovirology 6, 20.

D'Costa, J., Mansfield, S.G., Humeau, L.M., 2009. Lentiviral vectors in clinical trials: Current status. Current Opinion in Molecular Therapy 11, 554-64.

Davis, H.E., Rosinski, M., Morgan, J.R., Yarmush, M.L., 2004. Charged polymers modulate retrovirus transduction via membrane charge neutralization and virus aggregation. Biophysical Journal 86, 1234-42.

Gummuluru, S., Rogel, M., Stamatatos, L., Emerman, M., 2003. Binding of human immunodeficiency virus type 1 to immature dendritic cells can occur independently of DC-SIGN and mannose binding C-type lectin receptors via a cholesterol-dependent pathway. Journal of Virology 77, 12865-74.

Jacome, A., Navarro, S., Rio, P., Yanez, R.M., Gonzalez-Murillo, A., Lozano, M.L., Lamana, M.L., Sevilla, J., Olive, T., Diaz-Heredia, C., Badell, I., Estella, J., Madero, L., Guenechea, G., Casado, J., Segovia, J.C., Bueren, J.A., 2009. Lentiviral-mediated genetic correction of hematopoietic and mesenchymal progenitor cells from Fanconi anemia patients. Molecular Therapy 17, 1083-92.

Mason, A.J., Gasnier, C., Kichler, A., Prevost, G., Aunis, D., Metz-Boutigue, M.H., Bechinger, B., 2006a. Enhanced membrane disruption and antibiotic action against pathogenic bacteria by designed histidine-rich peptides at acidic $\mathrm{pH}$. Antimicrobial Agents and Chemotherapy 50, 3305-11.

Mason, A.J., Martinez, A., Glaubitz, C., Danos, O., Kichler, A., Bechinger, B., 2006b. The antibiotic and DNA-transfecting peptide LAH4 selectively associates with, and disorders, anionic lipids in mixed membranes. Faseb Journal 20, 320-2.

Merten, O.W., Charrier, S., Laroudie, N., Fauchille, S., Dugue, C., Jenny, C., Audit, M., Zanta-Boussif, M.A., Chautard, H., Radrizzani, M., Vallanti, G., Naldini, L., NoguiezHellin, P., Galy, A., 2011. Large-scale manufacture and characterization of a lentiviral vector produced for clinical ex vivo gene therapy application. Human Gene Therapy 22, 343-56.

Naldini, L., 2011. Ex vivo gene transfer and correction for cell-based therapies. Nature Reviews Genetic 12, 301-15.

Pollok, K.E., Williams, D.A., 1999. Facilitation of retrovirus-mediated gene transfer into hematopoietic stem and progenitor cells and peripheral blood T-lymphocytes utilizing recombinant fibronectin fragments. Current Opinion in Molecular Therapy 1, 595-604.

Sandrin, V., Boson, B., Salmon, P., Gay, W., Negre, D., Le Grand, R., Trono, D., Cosset, F.L., 2002. Lentiviral vectors pseudotyped with a modified RD114 envelope glycoprotein show increased stability in sera and augmented transduction of primary lymphocytes and CD34+ cells derived from human and nonhuman primates. Blood 100, 823-32. 


\section{Figure legends}

Fig. 1. Capacity of LAH4-L1 to enhance lentiviral transduction. (A) A variety of GFPencoding LV (GALVTR-LVs, MLV-A-LVs, RD114TR-LVs, VSV-G-LVs and VLPs) were used to transduce HCT116 cells $\left(1.2 \times 10^{5} \mathrm{TU} / \mathrm{ml}\right.$, MOI 0.6 or $200 \mathrm{ng} / \mathrm{ml}$ of HIV-1 p24 for VLPs) in absence or presence of 3, 6 or $12 \mu \mathrm{g} / \mathrm{ml}$ of LAH4-L1. Data are shown as the average percentage of GFP+ HCT116 cells \pm standard deviations (SD) $(n=3)$. (B) Data obtained in (A) are represented as the fold of enhancement mediated by LAH4-L1 with the mock condition normalized to one.

Fig. 2. Efficient transduction of hCD34+ cells with GALVTR-LVs in presence of LAH4-L1. (A) Determination of the $\mathrm{EC}_{50}$ of LAH4-L1 on hCD34+ cells transduced with GALVTR-LVs $\left(10^{6} \mathrm{TU} / \mathrm{ml}\right)$. Transduction efficiencies (percentage of GFP+ cells) were obtained 4 to 5 days post-transduction $(n=4)$. Data are normalized to the maximum effect observed \pm SD. (B) Determination of the $\mathrm{TC}_{50}$ of LAH4-L1. hCD34+ cells were incubated overnight with the indicated amount of LAH4-L1 ( $n=5)$. Next, the survival rate was estimated and normalized to the control condition \pm SD. (C) Transduction of hCD34+ cells with two different concentrations of GALVTR-LVs $\left(1\right.$ and $\left.2 \times 10^{6} \mathrm{TU} / \mathrm{ml}\right)$ in the absence or presence of LAH4L1 $(12 \mu \mathrm{g} / \mathrm{ml})$. Data are obtained from 7 different cord blood donors in simplicate or duplicate. (D) hCD34+ cells from two different donors were transduced in duplicate with GALVTRLVs either pre-incubated with LAH4-L1 $(12 \mu \mathrm{g} / \mathrm{ml})$ or pre-loaded onto retronectin coated plates $\left(20 \mu \mathrm{g} / \mathrm{cm}^{2}\right)$. Data are represented as the average percentage of GFP+ cells $\pm \mathrm{SD}$ $(* * \mathrm{p}<0.01, * \mathrm{p}<0.05$, Mann-Whitney test).

Fig. 3. GALVTR-LV binding assay in presence of LAH4-L1. (A) Protocol used for the virus binding assay is depicted. The experiment was done in triplicate. (B) Membrane bound p24 was determined using an ELISA p24 kit as described in the text and normalized to total protein content (total membrane of bound p24 in pg \pm SD). (C) Transduction efficiencies were determined as in Fig.1A and were represented as the average percentage of GFP+ cells \pm SD. (D) Transduction efficiencies were normalized to the number of membrane bound p24. An arbitrary unit of one was assigned to the "none" condition. $\left({ }^{*} p<0.05\right.$, not statistically significant (ns), Mann-Whitney test). 


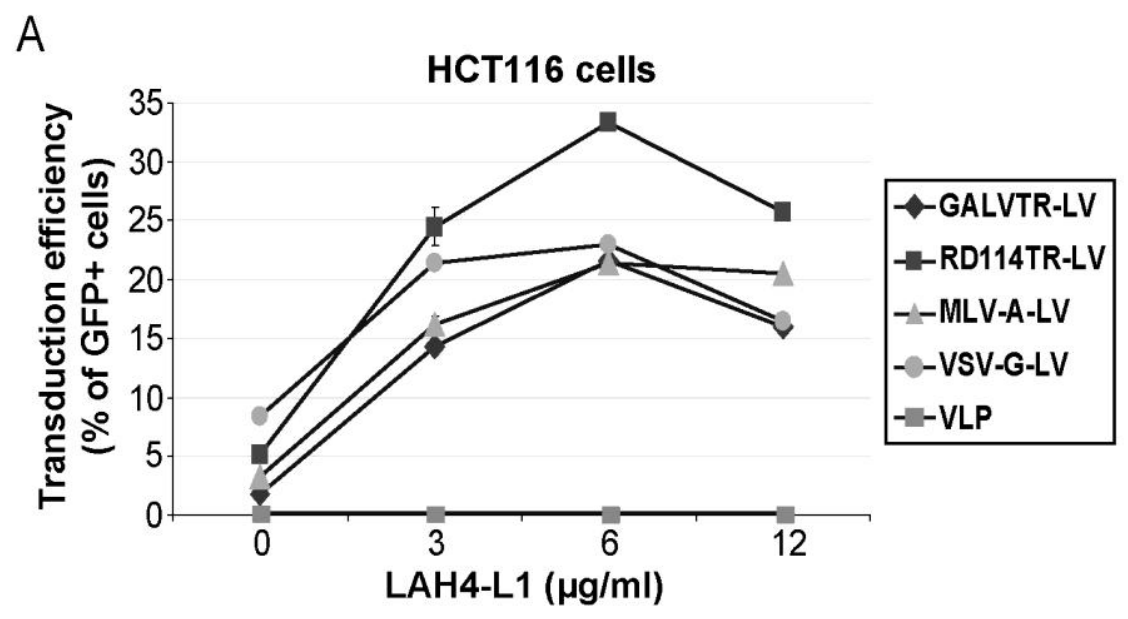

B

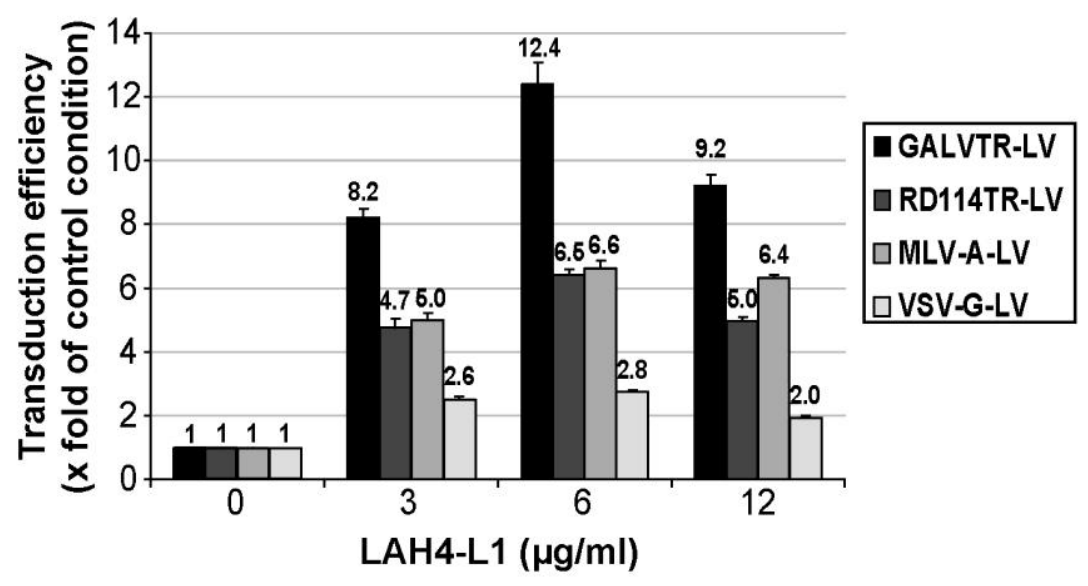

Fenard_et_al_Figure-1 


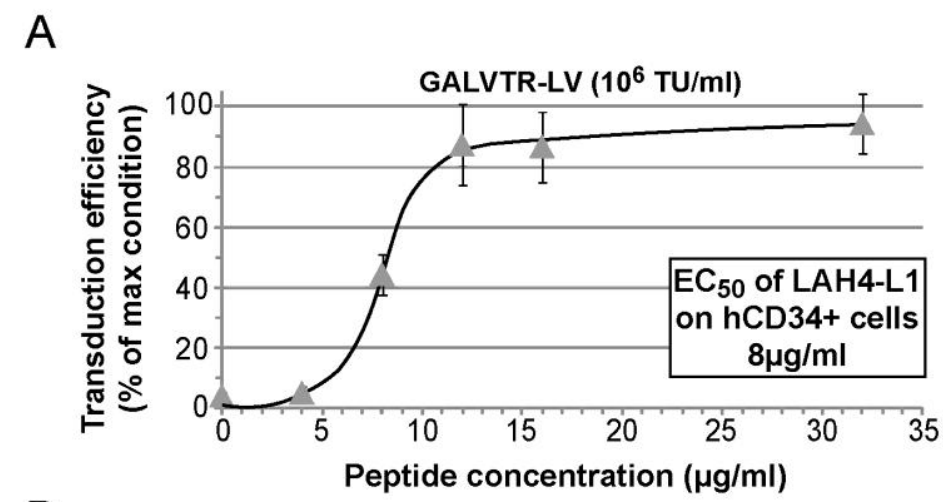

B

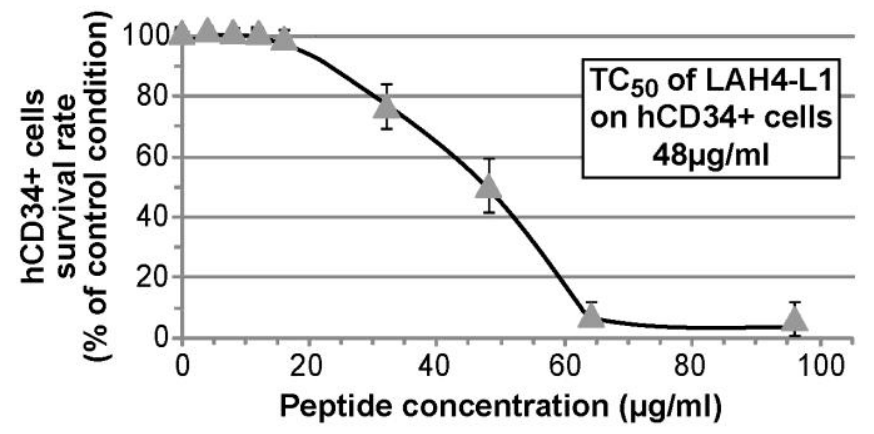

C

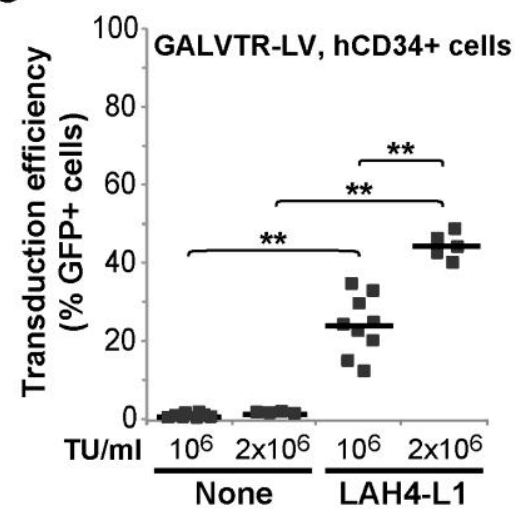

D

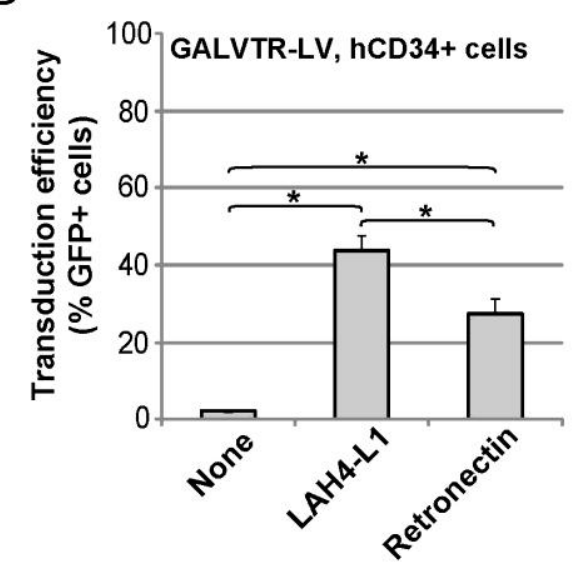

Fenard_et_al_Figure-2 


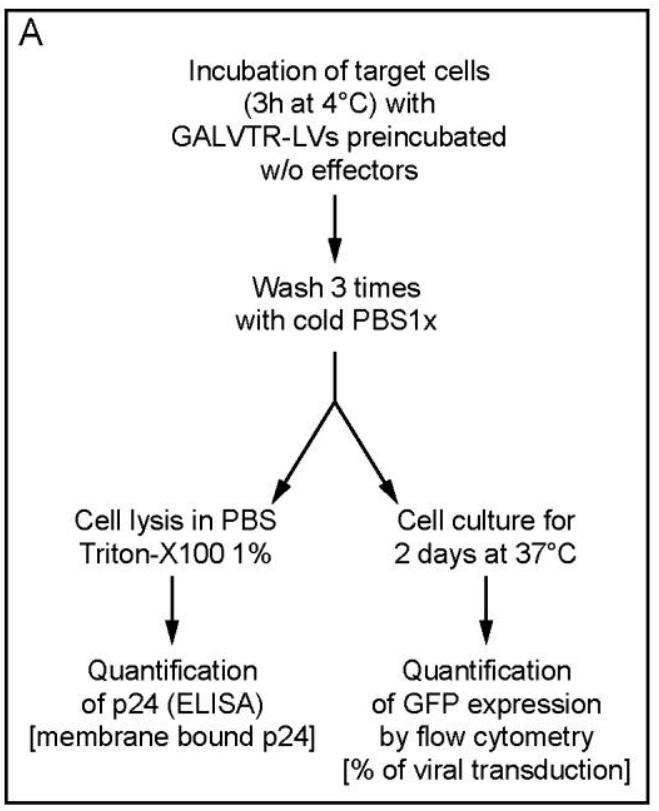

B

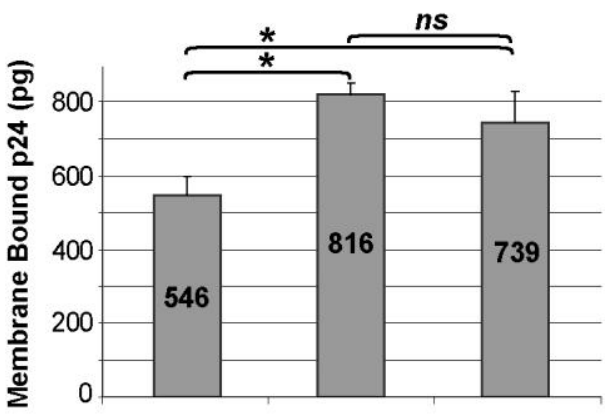

C

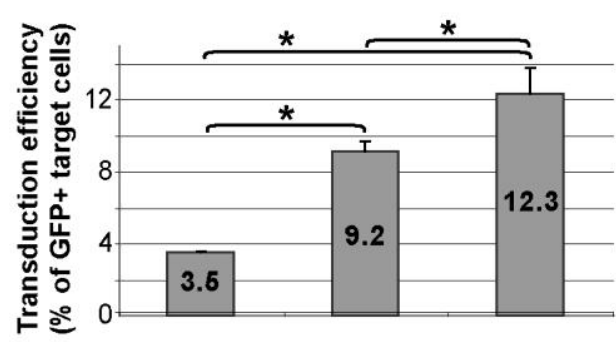

D

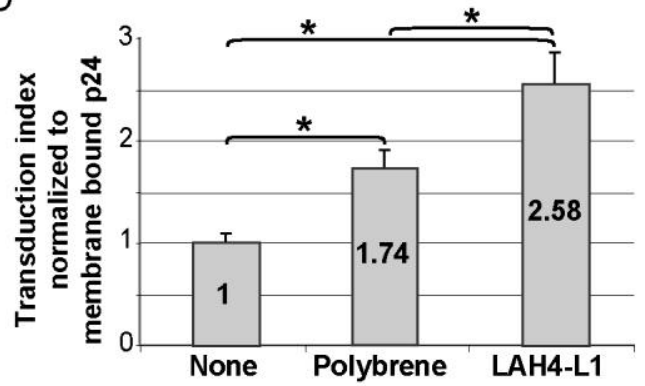

Fenard_et_al_Figure-3 